\title{
Reproductive parameters of eastern North Pacific blue whales Balaenoptera musculus
}

\author{
Richard Sears $^{1, *}$, Christian Ramp ${ }^{1,2}$, Annie B. Douglas ${ }^{3}$, John Calambokidis ${ }^{3}$ \\ ${ }^{1}$ Mingan Island Cetacean Study, 285 rue Green, St. Lambert, Quebec J4P 1T3, Canada \\ ${ }^{2}$ Scottish Oceans Institute, Sea Mammal Research Unit, University of St Andrews, Fife KY16 8LB, Scotland, UK \\ ${ }^{3}$ Cascadia Research Collective, 218 1/2 W 4th Avenue, Olympia, Washington 98501, USA
}

\begin{abstract}
Knowledge of reproduction in baleen whales such as the blue whale Balaenoptera musculus is still limited. Here, we combined the sighting histories of $24 \mathrm{yr}$ of reproductively active female blue whales from the United States (US) west coast and the Gulf of California (GoC), Mexico. The latter region is a nursing ground for some of the blue whales that feed off the US west coast during the summer months. We report here that females show site fidelity to the GoC even when not lactating. The mean calving interval based on consecutive sighting histories was $2.57 \mathrm{yr}$. Two female calves returned with their own offspring after 11 and $13 \mathrm{yr}$, indicating an apparent age of first parturition of $>10 \mathrm{yr}$. While $60 \%$ of females identified in the $\mathrm{GoC}$ were also sighted off the US west coast, only $30 \%$ of the females from the latter area were seen in the GoC. Thus only a part of the US Californian population migrates to the $\mathrm{GoC}$, suggesting the existence of additional calving and nursing grounds for this population. Despite the presence of killer whales, female blue whales presumably migrate to the GoC to benefit from high prey abundance. The lack of documented births in the GoC may indicate that female blue whales choose open, pelagic waters for calving and move to the GoC when the calves are older.
\end{abstract}

KEY WORDS: Blue whales $\cdot$ Reproduction $\cdot$ Calving intervals $\cdot$ Site fidelity $\cdot$ Migration

\section{INTRODUCTION}

By the 1960s, global blue whale Balaenoptera musculus populations had been severely depleted by whaling. Half a century later, understanding their reproductive rate and survival is one of the most important aspects of monitoring the recovery of these depleted populations. For most great whales, information about reproductive rate and age at first parturition is sparse. Certain baleen whale species, such as gray whales Eschrichtius robustus, right whales Eubalaena spp. and humpback whales Megaptera novaeangliae migrate to distinct breeding grounds, and numerous studies have provided valuable information concerning reproduction of these species (e.g. Jones \& Swartz 1984, Clapham \& Mayo 1987,
Knowlton et al. 1994). However, the mating and breeding behaviour in most balaenopterids is poorly known, and most knowledge is still largely based on whaling data.

Large numbers of blue whales Balaenoptera musculus feed off the west coast of the Unites States of America (hereafter, US west coast) and Canada during the summer months. The population off the US west coast and Mexico has been estimated to be around 3000 animals using line transect surveys and approximately 2000 using mark-recapture techniques (Calambokidis \& Barlow 2004). During summer months blue whale distribution ranges from southern California to the Queen Charlotte Islands and Alaska, with the highest concentration found off California (Calambokidis et al. 2009a). The distribution of north 
eastern Pacific blue whales in winter months is less well known; however, numerous blue whales are observed in the Gulf of California (GoC) and appear to belong to the same stock (Calambokidis et al. 1990) as blue whales encountered off the US west coast. Additional matches have been found to the west coast of the Baja Peninsula, Mexico and the Costa Rica Dome (Calambokidis et al. 1990, Mate et al. 1999, Stafford et al. 1999). Blue whales with young calves have been documented during winter months in the GoC (Sears 1990) and more recently from the Costa Rica Dome (Calambokidis et al. 2009b). Recent data suggest a decrease in abundance along the US west coast as a result of a shift in distribution to waters off British Columbia and Alaska (Calambokidis et al. 2009a).

Our knowledge concerning the reproductive system of blue whales is still largely based on Southern Ocean whaling data. As in most balaenopterids, female blue whales give birth to a single calf after a gestation period of 10 to $11 \mathrm{mo}$ and nurse the calf for 6 to 7 mo before weaning (Ottestad 1950, Yochem \& Leatherwood 1985). Mizroch (1981) estimated the pregnancy rate between 46 and $51 \%$ for the southern hemisphere. This would mean that every second mature female is pregnant, resulting in an average calving interval of $2 \mathrm{yr}$. Alaskan whaling data revealed that $27 \%$ of the females carried a foetus (Brueggemann et al. 1985), while North Atlantic International Whaling Commission catch records yielded a similar result of $23 \%$ (Ramp 2001), both resulting in approximate 4 yr calving intervals. Based on the number of wax layers deposited to form the earplug each year (Yochem \& Leatherwood 1985), sexual maturity is reached at between 5 and $10 \mathrm{yr}$ (Laurie 1937, Ruud et al. 1950, Lockyer 1984).

The mating system of blue whales is not well studied, and it appears unlikely that discrete mating/ breeding grounds exist unless they are far offshore. As in all other rorquals, blue whales are characterized by a small testis:body weight ratio (Brownell \& Ralls 1986), suggesting antagonistic male-male competition rather than sperm competition as the main mating strategy. Although blue whales are mostly observed to be solitary, an increase in male-female pairs has been observed at the approach of the winter breeding season in Eastern Canada (R. Sears pers. obs.). Occasionally, a second male joins these pairs causing dynamic surface behaviours including coursing, pursuit, and breaching by all 3 individuals, with physical contact between the males using head, body and tail swipes. These interactions lend support to the hypothesis of a (polygynous), antagonistic male-male mating strategy.
Here we use 2 long-term photo-identification studies, one from the US west coast and one from the $\mathrm{GoC}, \mathrm{Mexico}$, to estimate reproductive parameters for blue whales, using for the first time data from live whales. While the GoC is a known nursing area (Sears 1990), sightings of calves are rare off the US west coast. We compared the photo-identified females and calves from both areas to estimate calving intervals and re-sighting rates for within and between regions to investigate the distribution and migrations of females and calves during part of the winter.

\section{MATERIALS AND METHODS}

\section{Research areas}

Mingan Island Cetacean Study (MICS) conducted yearly surveys in the Gulf of California from 1983 to 2007, except 1994. Average annual effort was 18 survey-days in February/March when blue whale abundance is high and coincides with spawning of 2 species of euphausiids (Gendron 1992). The effort targeted the area Loreto (Fig. 1) and focused exclusively on blue whales. Cascadia Research Collective (CRC) conducted yearly surveys for blue whales off California from 1991 to 2007. Average annual effort for blue whales was 35 survey-days between June and October. Survey areas were selected to maximize the number of encounters, while attempting to maintain a broad temporal and geographic range along the US west coast (Calambokidis et al. 1990, Calambokidis \& Barlow 2004), with the main effort between $32^{\circ}$ and $42^{\circ} \mathrm{N}$. Only photographs collected along the US west coast were used in this comparison. Both MICS and CRC received numerous opportunistic photos and sightings of blue whales, especially from the 1980s, which were included in the analysis.

\section{Photo identification and sexing}

Blue whales were individually identified using photos of the flanks and backs of both sides. Females were identified as cows (i.e. lactating) due to the presence of a calf, which in turn was identified by its relatively small size (half the size) and positioning in synchronous swimming pattern while accompanying the female during several consecutive surfacing sequences in the same sighting over approximately an hour (Fig. 2). 


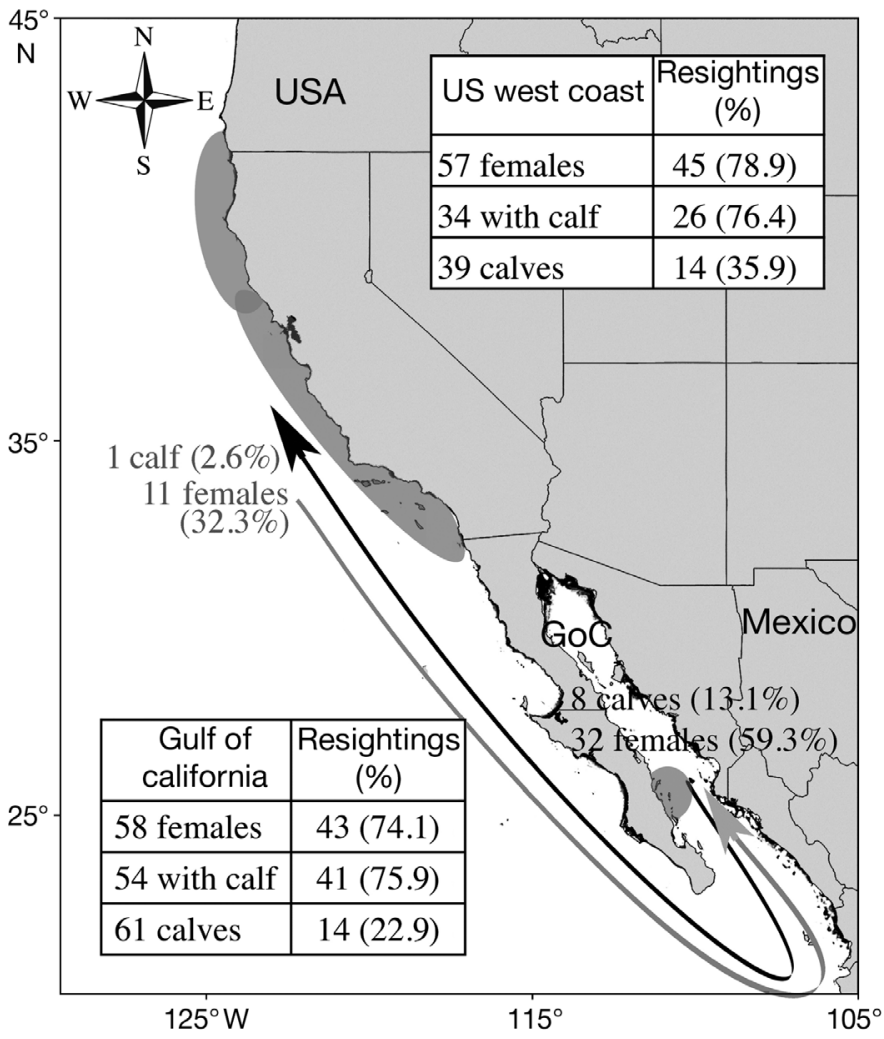

Fig. 1. Sightings and movements of females and calves between study areas on the US west coast and the Gulf of California (GoC). Boxes show sample sizes and resightings in both areas. The total number of females combines the number of observed lactating females in that area plus those identified there but sexed (seen with calf) in the other region. Numbers of females and calves resighted between regions are shown alongside the movement arrows, coloured grey for the US west coast and black for the GoC. The proportion of females moving from one area to the other was calculated using only females sighted with a calf in the source area. Shaded areas show approximate research areas for both regions

In the GoC, 398 individual blue whales were photoidentified from 1983 to 2007 . Of these, there were $54 \mathrm{fe}$ males with a total of 70 calves (of which 61 were photoidentified). Off the US west coast 1802 individuals were photo-identified from 1986 through 2006, including 34 females and 41 calves (39 photo-identified), which were compared to the known GoC females and calves. The females and calves of both regions were compared against each other. In case of a match the sighting histories were merged (Table 1) and used for the analysis.

\section{Calving intervals: Gulf of California}

We defined the calving interval of a female as the time in years between 2 consecutive calves. Usually successive annual sighting histories are used (e.g. Clapham \& Mayo 1990). Because this would have considerably reduced the sample size, we relaxed this assumption and assumed that the minimum calving interval is $2 \mathrm{yr}$. We counted a 2 -yr calving interval for a female sighted with calf in year $x$, not sighted the year after $(x+1)$, and sighted again with a calf the following year $(x+2)$. There is no evidence that blue whales can reproduce annually. We have restricted our analysis of calving intervals to sighting histories in the $\mathrm{GoC}$ due to the possibility that a female could have already weaned her calf by the time she was sighted off the US west coast.

\section{Crude birth rate: Gulf of California}

We estimated an annual crude birth rate for the GoC by dividing the total number of calves with the total number of identified individuals. The actual birth rate, the number of calves divided by the number of sexually mature females, could not be calculated due to lack of data on the number of females known to be sexually mature.

\section{Arrival times off the US west coast}

We calculated the average arrival dates of females on their summer feeding grounds (US west coast) based on the first day a female was photo-identified that year. We compared arrival dates between lactating (with calf) and non-lactating females (without calf), and between animals which had been seen earlier that same year in the GoC and those which had not.

\section{RESULTS}

\section{Matches between and within areas}

The comparison between catalogues of identified females and calves yielded 80 unique females (Table 1), of which 35 were seen in both areas, and 100 individual calves. The majority (32 of $54 ; \sim 60 \%$ ) of lactating females identified in the GoC were also photographed off the US west coast during the study period, while only a third (11 of 34) of observed lactating females from the US west coast were seen in the GoC (Fig. 1). On 11 occasions, females were sighted off the US west coast without a calf the same year that they had first been encountered with a calf 


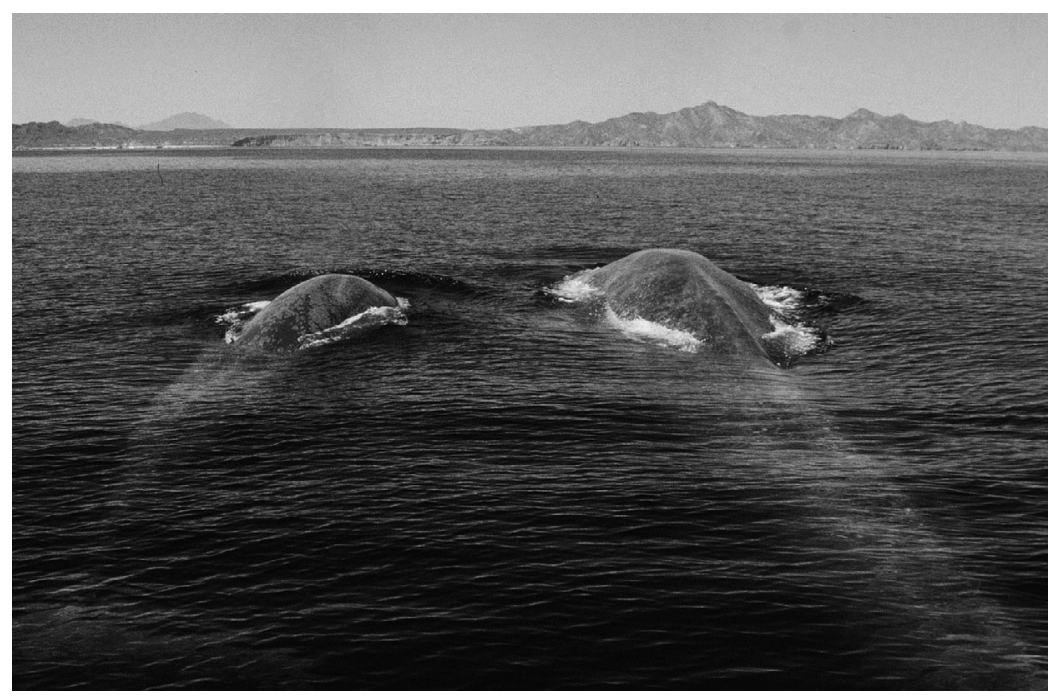

Fig. 2. Balaenoptera musculus. Cow (blue whale ID \# BB315) and calf (BB321) pair in the Gulf of California

in the GoC. Eight females were sighted with an accompanying calf in both regions, but in all cases these were different calves (years).

Twenty-eight calves were re-sighted after their year of birth as juveniles or adults, 14 in each area of the initial observation, representing $23 \%$ for the GoC calves, and $36 \%$ of the US calves. Sightings of calves between areas were rare. Of the 39 calves photographed off the US west coast, just one was sighted in a subsequent year in the $\mathrm{GoC}$, while of 61 calves photographed in the GoC, 8 were resighted off the US west coast. Four of these GoC calves were seen in US west coast waters in their year of birth, but were not recognized as calves at that time, because they were unaccompanied.

In the GoC 18 females were only encountered when they had a calf. All other females where sighted one or more times in the GoC without offspring (Table 1). One female was sighted in 13 different years in the $\mathrm{GoC}$, but only twice with a calf. Eleven females were seen in the year before having a calf (pregnant) in the GoC, 10 females in the year after (resting or pregnant).

\section{Birth rate, calving interval and age at apparent first birth}

We observed 22 calving intervals from the GoC, but only 7 female sight- ing histories were sufficiently complete to use. These comprised four 2-yr, two 3-yr and one 4-yr calving interval, resulting in a mean of $2.57 \mathrm{yr}$ $(\mathrm{SE}=0.3)$. Only 2 females observed as calves returned to the GoC with their own offspring, after 11 and 12 yr respectively. Neither was seen in the intervening years. The crude birth rate ranged from 0 to 0.25 (averaging 0.1 over all years) in the GoC.

\section{Arrival of females on the summer feeding grounds (US west coast)}

Arrivals of females at the feeding grounds off the US west coast appeared to be staggered. Lactating females which had not been seen earlier that year in the $\mathrm{GoC}$ were the first to arrive at the US west coast (mean arrival date of July 30), with non-lactating females unseen in the $\mathrm{GoC}$ tending to arrive $2 \mathrm{wk}$ later (mean: 15 August). Females which had been seen earlier that season in the GoC tended to arrive slightly later, and in contrast, the non-lactating females arrived earlier (mean: 17 August) than the lactating females (mean: 11 September; Fig. 3).

\section{DISCUSSION}

Despite the length of the study period, the number of females with calves was still low. The GoC appears

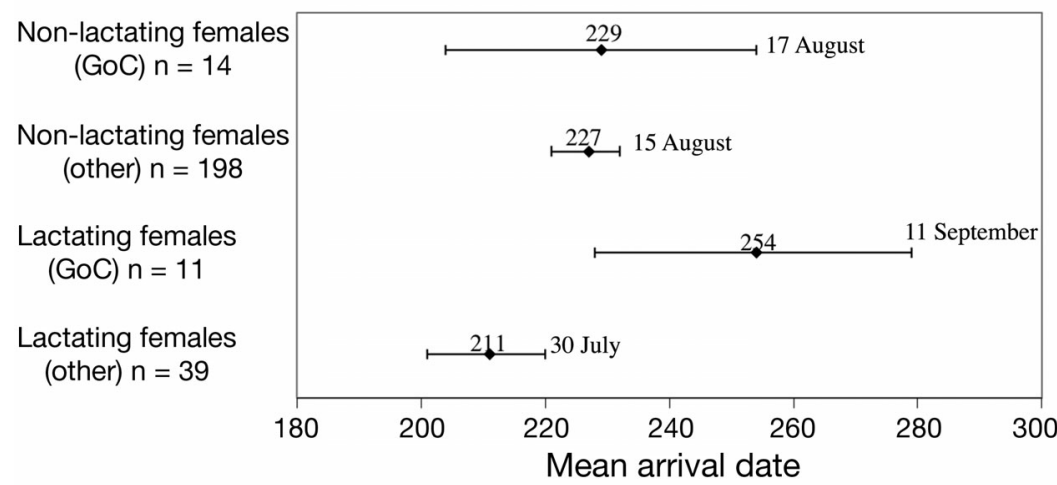

Fig. 3. Balaenoptera musculus. Date of arrival (as day of year) for blue whale females on the US west coast. Means (marked with calendar data) and 95\% confidence intervals are shown. Groups are differentiated into lactating and non-lactating females for individuals which had been observed earlier the same year in the Gulf of California (GoC), and those unobserved the previous winter (other) 
Table 1. Balaenoptera musculus. Sightings of breeding females with and without calves in both regions between 1984 and 2007. MICS: identification number from the Mingan Island Cetacean Study; CRC: identification number from the Cascadia Research Collective; G: sighting in the Gulf of California; U: US west coast. Bold letters indicate a sighting with a calf

\begin{tabular}{|c|c|c|c|c|c|c|c|c|c|c|c|c|c|c|c|c|c|c|c|c|c|c|c|c|c|}
\hline MICS & CRC & 84 & 85 & 86 & 87 & 88 & 89 & 90 & 91 & 92 & 93 & 94 & 95 & 96 & 97 & 98 & 99 & 00 & 01 & 02 & 03 & 04 & 05 & 06 & 07 \\
\hline BB008 & 322 & & & & $\mathrm{U}$ & $\mathrm{G}$ & & $\mathrm{U}$ & $\mathbf{G}$ & $\mathrm{U}$ & $\mathrm{U}$ & $\mathrm{U}$ & & $\mathrm{U}$ & & & & & $\mathrm{U}$ & & & & & & \\
\hline BB009 & 423 & $\mathrm{G}$ & G & G/U & & $\mathrm{G}$ & G & & & $\mathrm{U}$ & & $\mathrm{U}$ & $\mathrm{U}$ & G & $\mathbf{G}$ & G & & & G & $\mathrm{G}$ & G/U & & G & $\mathrm{G}$ & \\
\hline BB014 & 449 & & & & & G & & G & & & & & $\mathbf{G}$ & & G & & & & & & & & $\mathrm{G}$ & $\mathrm{G}$ & \\
\hline BB028 & 459 & & G & & & $\mathrm{G}$ & $\mathrm{U}$ & G & & U & U & & & G & $\mathrm{G}$ & U & & & $\mathrm{G} / \mathrm{U}$ & G & $\mathrm{U}$ & & G & $\mathrm{G}$ & \\
\hline BB032 & 401 & & $\mathbf{G}$ & G & & $\mathrm{G} / \mathrm{U}$ & $\mathrm{U}$ & & G & $\mathrm{U}$ & & & & & & & & & & $\mathrm{U}$ & $\mathrm{U}$ & & & & \\
\hline BB036 & & & $\mathbf{G}$ & & & & & $\mathrm{G}$ & $\mathrm{G}$ & & & & & & & & & & & G & & G & G & & \\
\hline BB037 & & & G & & & & & & & & & & & & G & & & & & & & & & G & \\
\hline BB038 & 1060 & & $\mathrm{G}$ & & & & & G & & & & & $\mathrm{U}$ & $\mathrm{U}$ & & G & & $\mathrm{G}$ & G & & & & & $\mathrm{G}$ & \\
\hline BB042 & 1627 & & $\mathrm{G}$ & & & & & & & & & & $\mathbf{G}$ & & & & & $\mathrm{G} / \mathrm{U}$ & $\mathrm{J}$ & & $\mathbf{U}$ & & G & & \\
\hline BB050 & 246 & & $\mathbf{G}$ & & & $\mathrm{G} / \mathrm{U}$ & $\mathrm{U}$ & G/U & & & & $\mathrm{U}$ & $\mathbf{G}$ & & & & & & & & G/U & & $\mathbf{G}$ & & $\mathrm{G}$ \\
\hline BB052 & & & $\mathrm{G}$ & $\mathbf{G}$ & & & & & G & & & & & & G & & G & & $\mathrm{G}$ & $\mathrm{G}$ & & G & & & $\mathrm{G}$ \\
\hline BB061 & 978 & & & & G & & & & & & & $\mathrm{U}$ & $\mathrm{U}$ & & & G & & & & & G & & G & G & $\mathbf{G}$ \\
\hline BB063 & & $\mathrm{G}$ & G & G & & & & G & $\mathrm{G}$ & & & & G & & $\mathbf{G}$ & & G & & $\mathrm{G}$ & $\mathrm{G}$ & $\mathbf{G}$ & G & & & \\
\hline BB072 & & & & & $\mathbf{G}$ & & & & & & & & & & & & & & & & & & & & \\
\hline BB124 & 15 & & & $\mathrm{U}$ & & & $\mathrm{U}$ & $\mathrm{U}$ & & $\mathbf{U}$ & & $\mathrm{U}$ & & & & & $\mathrm{U}$ & & $\mathrm{G}$ & $\mathrm{U}$ & & & $\mathrm{U}$ & $\mathrm{U}$ & \\
\hline BB132 & 442 & & & $\mathrm{U}$ & & $\mathrm{U}$ & & & & & & & & & & & $\mathrm{U}$ & & $\mathbf{U}$ & $\mathrm{U}$ & $\mathrm{U}$ & & & & \\
\hline BB143 & & & & & & $\mathrm{G}$ & & $\mathbf{G}$ & & & & & & & $\mathrm{G}$ & & & & G & & & & & & \\
\hline BB146 & & & & & & $\mathrm{G}$ & $\mathbf{G}$ & & & & & & & & & & & & & & & & & & \\
\hline BB152 & 1273 & & & & & $\mathbf{G}$ & G & $\mathbf{G}$ & G & $\mathrm{G}$ & & & G & $\mathrm{G} / \mathrm{U}$ & & G & G & & & & & G & & & \\
\hline BB153 & 104 & & & & $\mathrm{U}$ & & G/U & $\mathrm{U}$ & & & & & & & & & & & & & & & & & \\
\hline BB159 & 261 & & & & & $\mathrm{G} / \mathrm{U}$ & $\mathbf{G}$ & & $\mathrm{U}$ & $\mathrm{U}$ & & $\mathbf{U}$ & & & & $\mathrm{G} / \mathrm{U}$ & & & & & & & & & \\
\hline BB162 & & & & & & & G & $\mathrm{G}$ & $\mathbf{G}$ & & & & & & & & & & & & & & & & \\
\hline BB163 & & & & & & & G & & & & & & & & & & G & $\mathbf{G}$ & & $\mathrm{G}$ & & & & & \\
\hline BB166 & & & & & G & & & & & & & & & & & & & & & & & & & & \\
\hline BB170 & 1258 & & & & & & & $\mathrm{G}$ & $\mathrm{G}$ & & & & & $\mathrm{U}$ & & $\mathrm{U}$ & & & & & $\mathbf{G}$ & & & & G \\
\hline BB176 & 1632 & & & & & & & $\mathbf{G}$ & & & & & & & & & & U & G/U & & $\mathrm{U}$ & & & & \\
\hline BB182 & & & & & G & & & & & & $\mathrm{G}$ & & & & & & & & & & & & & G & \\
\hline BB185 & & & & & & & & $\mathrm{G}$ & & & & & & & & & & & & & & & & & G \\
\hline BB205 & & & & & & & & & & & & & & & & & $\mathbf{G}$ & & $\mathrm{G}$ & & G & & $\mathrm{G}$ & $\mathrm{G}$ & $\mathrm{G}$ \\
\hline BB206 & 595 & & & & & G/U & & $\mathrm{G}$ & & U & U & $\mathrm{U}$ & $\mathbf{U}$ & $\mathrm{G}$ & $\mathbf{U}$ & $\mathrm{G} / \mathrm{U}$ & $\mathrm{G}$ & $\mathrm{U}$ & & & $\mathrm{U}$ & & & $\mathrm{U}$ & \\
\hline BB215 & 811 & & & & & & & $\mathbf{G}$ & & $\mathrm{U}$ & & $\mathbf{U}$ & & & & & & & & & & & & & \\
\hline BB217 & 1477 & & & & & & & $\mathbf{G}$ & & G & & & & & & $\mathrm{U}$ & $\mathrm{U}$ & & & & & & & & \\
\hline BB220 & 930 & & & & & & & $\mathbf{G}$ & $\mathrm{G}$ & & & $\mathbf{U}$ & & $\mathbf{U}$ & $\mathrm{U}$ & $\mathrm{U}$ & & & & & & & & & \\
\hline BB238 & & & & & & & & & $\mathbf{G}$ & & & & & & & & & & & & & & & & \\
\hline BB240 & 271 & & & G & $\mathbf{G}$ & $\mathrm{G} / \mathrm{U}$ & & & & $\mathbf{G}$ & & & $\mathbf{U}$ & $\mathrm{U}$ & & & $\mathrm{U}$ & & & & & & $\mathrm{U}$ & & \\
\hline BB247 & & & & & & & & & & & & & & & & & $\mathbf{G}$ & & $\mathbf{G}$ & & & & & & \\
\hline BB249 & & & & & & & & & & & & & $\mathbf{G}$ & & & & & & & & & & & & \\
\hline BB255 & 763 & & & & & & & & & $\mathrm{U}$ & & & $\mathrm{U}$ & G/U & $\mathrm{U}$ & & & & $\mathbf{U}$ & $\mathrm{U}$ & & & & $\mathrm{U}$ & \\
\hline BB257 & 1436 & & & & & & & & & & & & & $\mathbf{G}$ & & $\mathrm{U}$ & & & & & & & & & \\
\hline BB259 & 486 & & & & & & $\mathrm{G}$ & & & & & & $\mathrm{U}$ & $\mathrm{G}$ & & $\mathbf{G}$ & & & G/UC & $\mathrm{G} / \mathrm{U}$ & $\mathrm{J} \mathrm{U}$ & $\mathbf{G}$ & $\mathrm{G}$ & $\mathrm{G}$ & \\
\hline BB271 & 701 & & & & & & & $\mathbf{U}$ & & $\mathrm{U}$ & & & & & $\mathrm{G}$ & $\mathrm{U}$ & $\mathrm{U}$ & & & & & $\mathrm{U}$ & & & \\
\hline BB272 & 963 & & & & & & & & & & & $\mathrm{U}$ & & & $\mathrm{G} / \mathrm{U}$ & & & & & & & & & & \\
\hline BB286 & 1681 & & & & & & & & & & & & & & & G & & & G/U & U & & $\mathrm{U}$ & & $\mathrm{U}$ & \\
\hline BB289 & 1294 & & & & & & & & & & & & & $\mathrm{U}$ & $\mathrm{G}$ & & $\mathrm{U}$ & & G & & $\mathrm{G}$ & $\mathrm{U}$ & & & \\
\hline BB296 & 1417 & & & & & & & & & & & & & & & G/U & & & & & $\mathbf{G}$ & & & & \\
\hline BB298 & 1666 & & & & $\mathrm{G}$ & & & & & & & & & & & G & & $\mathrm{U}$ & & & & & $\mathrm{U}$ & & \\
\hline BB300 & & & & & & & & & & & & & & & & $\mathbf{G}$ & & & & & & & & & \\
\hline BB302 & 1362 & & & & & & & & & & & & & & $\mathrm{U}$ & $\mathbf{G}$ & & & & & $\mathrm{U}$ & & & & G \\
\hline BB315 & 2252 & & & & & & & & & & & & & & & & & & $\mathbf{G}$ & & G & & $\mathbf{G}$ & $\mathrm{U}$ & \\
\hline & 455 & & & & & $\mathrm{U}$ & $\mathrm{U}$ & & & $\mathrm{U}$ & & & & $\mathbf{U}$ & $\mathrm{U}$ & $\mathrm{U}$ & $\mathrm{U}$ & & $\mathrm{U}$ & $\mathrm{U}$ & $\mathbf{G}$ & & & & G \\
\hline BB344 & 402 & & & & & U & & & & & $\mathrm{U}$ & & & & & U & & & U & & $\mathbf{G}$ & G & & & \\
\hline BB352 & 345 & & & & $\mathrm{U}$ & G/U & & & $\mathrm{U}$ & $\mathrm{U}$ & $\mathrm{U}$ & $\mathrm{U}$ & $\mathrm{U}$ & $\mathrm{U}$ & $\mathrm{U}$ & $\mathrm{U}$ & $\mathrm{U}$ & $\mathrm{U}$ & $\mathrm{U}$ & & $\mathrm{G} / \mathrm{U}$ & $\mathrm{G} / \mathrm{U}$ & G & & G \\
\hline BB374 & 1292 & & & & & & & & & & & & & $\mathrm{U}$ & $\mathrm{U}$ & & & & $\mathrm{U}$ & & & $\mathrm{U}$ & G & & \\
\hline BB376 & & & & & & & & & & & & & & & & & & & & & & & G & $\mathrm{G}$ & \\
\hline BB378 & & & & & & & & & & & & & & & & & & & & & & & $\mathbf{G}$ & & \\
\hline
\end{tabular}


Table 1 (continued)

\begin{tabular}{|c|c|c|c|c|c|c|c|c|c|c|c|c|c|c|c|c|c|c|c|c|c|c|c|c|}
\hline MICS & CRC 84 & 85 & 86 & 87 & 88 & 89 & 90 & 91 & 92 & 93 & 94 & 95 & 96 & 97 & 98 & 99 & 00 & 01 & 02 & 03 & 04 & 05 & 06 & 07 \\
\hline \multirow{25}{*}{ BB409 } & 519 & & & & & U & U & & U & & & & $\mathbf{U}$ & & & U & & U & U & $\mathrm{U}$ & $\mathbf{U}$ & U & & G \\
\hline & 3 & & U & & U & $\mathrm{U}$ & $\mathrm{U}$ & U & $\mathrm{U}$ & $\mathbf{U}$ & & U & U & U & & $\mathrm{U}$ & U & & & & U & & & \\
\hline & 12 & U & U & U & & U & U & U & $\mathbf{U}$ & U & & U & U & U & U & $\mathbf{U}$ & U & & U & & & & & \\
\hline & $471 \mathbf{G}$ & G & & & & & & & & & & & & & & & & & & & & & & \\
\hline & 438 & & $\mathbf{U}$ & & & & & & & & & & & & & & & & & & & & & \\
\hline & 101 & & & U & $\mathbf{U}$ & U & U & & U & & & & & U & U & & & & & & $\mathbf{U}$ & & & \\
\hline & 497 & & & & & G & & & & & & & & & & & & & & & & & & \\
\hline & 569 & & & & & & $\mathbf{U}$ & & & & & & & & & & & & & & & & & \\
\hline & 798 & & & & & & & & $\mathbf{U}$ & & & & & & & & & & & & & & & \\
\hline & 34 & & U & U & U & & U & & U & $\mathbf{U}$ & U & & & U & & U & & U & $\mathbf{U}$ & U & & & & \\
\hline & 378 & & & U & & & U & & & $\mathbf{U}$ & & U & & & & & & & & & & U & & \\
\hline & 1151 & & & & & & & & & & & $\mathbf{U}$ & & & & & & & & & & & & \\
\hline & 683 & & & & & & & & U & & & & $\mathbf{U}$ & & U & & & & & & & & & \\
\hline & 682 & & & & & & & & U & & U & U & U & $\mathbf{U}$ & U & U & & U & & & U & & & \\
\hline & 604 & & & & & & U & & & & U & & & & $\mathbf{U}$ & & & U & & & U & $\mathbf{U}$ & U & \\
\hline & 783 & & & & & & & & U & & & & & U & $\mathbf{U}$ & U & & U & U & & U & & & \\
\hline & 1126 & & & & & & & & & & & U & & & & U & & & & & & & & \\
\hline & 710 & & & & & & & & U & & & & & & & & & U & & & & & & \\
\hline & 1475 & & & & & & & & & & & & & & U & & & $\mathbf{U}$ & U & U & & & & \\
\hline & 1989 & & & & & & & & & & & & & & & & & & & $\mathbf{U}$ & & U & & \\
\hline & 2152 & & & & & & & & & & & & & & & & & & & & $\mathbf{U}$ & & & \\
\hline & 2153 & & & & & & & & & & & & & & & & & & & & & U & & \\
\hline & 2301 & & & & & & & & & & & & & & & & & & & & & & $\mathbf{U}$ & \\
\hline & 2330 & & & & & & & & & & & & & & & & & & & & & & $\mathbf{U}$ & \\
\hline & 988 & & & & & & & & & & U & & & & & & & U & & & & U & $\mathbf{U}$ & \\
\hline
\end{tabular}

to be a nursing area for blue whales of the northeast Pacific stock, although only a portion of the population uses these waters regularly. Females returned to GoC with and without calves, indicating that the area is also important as a feeding area and is regularly used by females in different reproductive states. No blue whale birth has ever been observed in the eastern north Pacific or anywhere else. This is not surprising, however, because it is also true for humpback whales, which have well-documented and monitored breeding/calving grounds. Due to the timing of sightings in the GoC and the apparent time of weaning in early summer, the observed calves appear to have been between 2 and 4 mo old. Our observations do not reveal whether these calves were born in the vicinity of the GoC or travelled there with their mothers in late winter or early spring from another location.

Calving intervals can be as short as $2 \mathrm{yr}$, as documented with pregnancy rates in whaling data (Mizroch 1981), but our observations suggest that intervals are on average longer. Estimates based on uninterrupted sighting histories are biased low, since longer birth intervals are less likely to be observed (Barlow \& Clapham 1997). The same authors acknowledge that calving intervals based on sight- ings on the feeding grounds are based on the survival of the calf, which would bias the interval upwards. However, we still suggest that the estimated $2.57 \mathrm{yr}$ interval in this study is likely an underestimation. The value was similar to humpback whales, whose mean birth interval is estimated at 2.38 yr (Barlow \& Clapham 1997). It seems noteworthy that the pregnancy rates in the southern hemisphere (Mizroch 1981) are almost twice as high as in the northern hemisphere (Brueggemann et al. 1985, Ramp 2001). We were not able to calculate the age at apparent first birth, because the 2 females (ID \#BB037 and ID \#BB298, see Table 1) first sighted as calves, then observed with their own offspring, were not sighted in the intervening years. However, taking into account the number of calves re-sighted, such observations should be more numerous now if these blue whales had reached sexual maturity earlier than at age 10. It appears more likely that blue whales have their first calf after age 10, such as shown for a humpback whale population (Gabriele et al. 2007).

Because sightings of calves off the US west coast were rare after July, weaning of calves appears to occur in early summer during the migration to or on the feeding grounds. This is supported by the fact all 11 females sighted with a calf in the GoC were seen 
alone off the US west coast and that the 4 (GoC) calves sighted off California in their year of birth were unaccompanied. This raises the question as to where the lactating females sighted off California originate. The total number of calves observed in the $\mathrm{GoC}$ (never more than 10 in a given year) is very low in relation to recent population estimates (Calambokidis \& Barlow 2004) and it is unlikely that all calves are born or nursed in the GoC. Few surveys have been carried out in Mexican and Central American waters during winter months; however, at least one calf was observed in the vicinity of the Costa Rican Dome January 2008 (Calambokidis et al. $2009 b)$, indicating another possible calving ground. Because none of the 11 females with a calf observed in the $\mathrm{GoC}$ was recognized as a lactating animal off California, females with a calf could have come from a different area, i.e. from the west coast of Baja or further south. This suggests the existence of several calving or nursing areas with different migration lengths to the summer feeding grounds. The return of 2 former calves with their own offspring might indicate a certain maternally directed site fidelity to a nursing area. This is supported by the fact that calves first identified in the GoC were regularly encountered in the same region in subsequent years, while only one calf from California was sighted in the GoC. It is also worth noting that while $60 \%$ of the females in the GoC were matched to the US west coast summer feeding grounds, only $33 \%$ of the females from California were also observed in the GoC. It is, however, at this time difficult to determine if distinct calving areas exist, and if these overlap at all with their apparently flexible mating grounds (Payne \& Webb 1971).

\section{Why do blue whales migrate?}

There is an ongoing discussion as to why some baleen whales migrate in spring and fall (see e.g. Corkeron \& Connor 1999, Clapham 2001). Several hypotheses have been proposed, dismissed and reformulated. Here we discuss potential beneficial factors which may influence female blue whales to migrate to the GoC. Corkeron \& Connor (1999) suggested that predation by killer whales Orcinus orca is the prime evolutionary force for baleen whale migration. They argue that killer whale abundance is greater in polar waters and that females minimize the risk to calves by migrating from subtropical/tropical to temperate waters. The majority of blue whales summer in the temperate California waters but still migrate south to calve. Killer whales are frequently sighted in the GoC (Guerrero-Ruiz et al. 1998) and could pose a threat to blue whale calves. Approximately $25 \%$ of blue whales from the GoC carry killer whale rake marks (Sears \& Calambokidis 2002), and killer whales are present at both summer and winter grounds. In a recent analysis, Mehta et al. (2007) showed that most baleen whales are not an important prey for killer whales. The animals nursing their calves in the GoC do so despite the common threat of killer whales encounters. However, we do not know where the animals are born, and a large proportion of the females give birth in different (most likely more pelagic) waters. Thus, they might select more offshore waters to avoid predation (Ford \& Reeves 2008), at least in the first weeks or months.

Further hypotheses included thermoregulation of females and calves and relatively calm waters to give birth (Norris 1967, Brodie 1975, Whitehead \& Moore 1982, Payne 1995, Clapham 1996). The Gulf of California has relatively warm surface waters year-round (coldest in January with an average surface temperature of $19^{\circ} \mathrm{C}$ ) and is relatively protected from ocean swell (Alvarez-Borrego 1983), thus supporting this theory. However, we observed many females in the GoC without calves, who were pregnant or resting, and found no clear evidence that they gave birth there. Although births are of course possible, the fact that many non-lactating blue whales choose the area does not indicate that 'calmer and warmer water' is the prime reason for the occurrence of these whales.

In addition, we observed many surface feeding events. The occurrence of blue whales in spring corresponds to the spawning of the small euphausiid Nyctiphanes simplex (Gendron 1992). Lactating females have especially high energy demands (Lockyer 1981), and these females are often identifiable by sloughing skin and appear to be thin, in that the vertebral processes are distinctly visible along their backs. Thus, blue whales may to come to the GoC to access available food resources outside their feeding areas, as suggested by Payne (1995). The Costa Rica Dome could be another area where blue whale females give birth and find prey in abundance at the same time.

This study suggests that female blue whales seem to reproduce later in life and less frequently than other species, such as the humpback whale. These females select productive areas to nurse, enabling them to feed outside their main feeding areas and season. Continued research in known areas of occurrence and further exploration of other potential habitats (western Baja and off central America) will be 
required to obtain more data. Satellite tagging may also be useful to determine where females migrate in winter, especially if their reproductive status (pregnant/resting) is known.

Acknowledgements. R.S. and C.R. (of MICS) thank Diane Gendron and Lorenzo Rojas for their assistance with the Mexican permits. Special thanks to Bill and Betty Riffe for their wonderful hospitality, to Isidro and Fernando for their marine logistical support, and to MICS team members over the years, as well as Jordan Kimbriel, Michael Fishback, and Urmas Kaldveer for additional data. A.B.D. and J.C. (of CRC) thank Southwest Fisheries Science Center for photos and support and Lisa Schlender for blue whale matching as well as volunteers and interns at CRC. We also thank 3 anonymous reviewers for their efforts and useful comments on this text. All research was conducted under Mexican and US research permits.

\section{LITERATURE CITED}

Alvarez-Borrego B (1983) Gulf of California. In: Ketchum BH (ed) Ecosystems of the world: estuaries and enclosed seas. Elsevier, Amsterdam, p 427-449

$>$ Barlow J, Clapham PJ (1997) A new birth-interval approach to estimating demographic parameters of humpback whales. Ecology 78:535-546

Brodie PF (1975) Cetacean energetics, an overview of intraspecific size variation. Ecology 56:152-161

Brownell RL, Ralls K (1986) Potential for sperm competition in baleen whales. Rep Int Whal Comm 8(Spec Issue): 97-112

Brueggemann JJ, Newby TC, Grotefendt RA (1985) Seasonal abundance, distribution and population characteristics of blue whales reported in the 1917-1939 catch records of two Alaska whaling stations. Rep Int Whal Comm 35:405-411

Calambokidis J, Barlow J (2004) Abundance of blue and humpback whales in the eastern North Pacific estimated by capture-recapture and line-transect methods. Mar Mamm Sci 20:63-85

Calambokidis J, Steiger GH, Cubbage JC, Balcomb KC and others (1990) Sightings and movements of blue whales off Central California 1986-88 from photo-identification of individuals. Rep Int Whal Comm 12(Spec Issue): 343-348

> Calambokidis J, Barlow J, Ford JKB, Chandler TE, Douglas AB (2009a) Insights into the population structure of blue whales in the eastern North Pacific from recent sightings and photographic identification. Mar Mamm Sci 25: 816-832

Calambokidis J, Mate BR, Oleson EM, Irvine LCH, Douglas AB (2009b) The Costa Rica Dome as a winter feeding and breeding areas for North Pacific blue whales (Abstract) In: Proc 18th Biennial Conference on the Biology of Marine Mammals, Quebec

$>$ Clapham PJ (1996) The social and reproductive biology of humpback whales: an ecological perspective. Mammal Rev 26:27-49

Clapham PJ (2001) Why do baleen whales migrate? A response to Corkeron and Connor. Mar Mamm Sci 17: 432-436
Clapham PJ, Mayo CA (1987) Reproduction and recruitment of individually identified humpback whales, Megaptera novaeangliae, observed in Massachusetts Bay, 19791985. Can J Zool 65:2853-2863

Clapham PJ, Mayo CA (1990) Reproduction of humpback whales (Megaptera novaeangliae) observed in the Gulf of Maine. Rep Int Whal Comm 12(Spec Issue): 171-175

Corkeron PJ, Connor RC (1999) Why do baleen whales migrate? Mar Mamm Sci 15:1228-1245

Ford JKB, Reeves R (2008) Fight or flight: antipredator strategies of baleen whales. Mammal Rev 38:50-86

Gabriele CM, Straley JM, Neilson JL (2007) Age at first calving of female humpback whales in southeastern Alaska. Mar Mamm Sci 23:226-239

Gendron D (1992) Population structure of daytime surface swarms of Nyctiphanes simplex (Crustacea: Euphausiacea) in the Gulf of California, Mexico. Mar Ecol Prog Ser 87:1-6

Guerrero-Ruiz M, Gendron D, Urban J (1998) Distribution, movements and communities of killer whales (Orcinus orca) in the Gulf of California, Mexico. Rep Int Whal Comm 48:537-543

Jones ML, Swartz SL (1984) Demography and phenology of gray whales and evaluation of whale-watching activities in Laguna San Ignacio, Baja California Sur, Mexico. In: Jones ML, Swartz SL, Leatherwood S (eds) The gray whale, Eschrichtius robustus. Academic Press, Orlando, FL, p 309-374

$>$ Knowlton AR, Kraus SD, Kenney RD (1994) Reproduction in North Atlantic right whales (Eubalaena glacialis). Can J Zool 72:1297-1305

Laurie AH (1937) The age of female blue whales and the effect of whaling on the stock. Disc Rep 15:223-284

Lockyer CH (1981) Growth and energy budgets of large baleen whales from the southern hemisphere. In: FAO Advisory Committee on Marine Resource Research (ed) Mammals in the seas, Vol III. FAO, Rome, p 379-487

Lockyer CH (1984) Review of baleen whale (Mysticeti) reproduction and implication for management. Rep Int Whal Comm 6(Spec Issue):27-50

Mate BR, Lagerquist BA, Calambokidis J (1999) Movements of North Pacific blue whales during the feeding season off southern California and their southern fall migration. Mar Mamm Sci 15:1246-1257

Mehta AV, Allen JM, Constantine R, Garrigue C and others (2007) Baleen whales are not important as prey for killer whales Orcinus orca in high-latitude regions. Mar Ecol Prog Ser 348:297-307

Mizroch SA (1981) Further notes on southern hemisphere baleen whale pregnancy rates. Rep Int Whal Comm 31: 629-633

Norris KS (1967) Some observations on the migration and orientation of marine mammals. In: Storm RM (ed) Animal orientation and navigation. Oregon State University Press, Corvallis, OR, p 101-125

Ottestad P (1950) On age and growth of blue whales. Hvalradets Skr 33:67-72

Payne R (1995) Among whales. Scribner, New York, NY

Payne R, Webb D (1971) Orientation by means of long range acoustic signalling in baleen whales. Ann NY Acad Sci 188:110-141

Ramp C (2001) On the population dynamics and ecology of Canadian and Mexican blue whales (Balenopetera musculus). Masters thesis, University of Bremen 
Ruud JT, Jonsgard A, Ottestad P (1950) Age studies on blue whales. Hvalradets Skr 33:5-66

Sears R (1990) The Cortez blues. Whalewatcher 24:12-15

Sears R, Calambokidis J (2002) COSEWIC assessment and update status report on the blue whale Balaenoptera musculus in Canada. Committee on the Status of Endangered Wildlife in Canada, Ottawa

Stafford KM, Nieukirk SL, Fox CG (1999) An acoustic link between blue whales in the eastern tropical Pacific and

Editorial responsibility: Sascha Hooker, St. Andrews, UK the northeast Pacific. Mar Mamm Sci 15:1258-1268

Whitehead H, Moore MJ (1982) Distribution and movements of West Indian humpback whales in winter. Can J Zool 60:2203-2211

Yochem PK, Leatherwood S (1985) Blue whale Balaenoptera musculus (Linnaeus, 1758). In: Ridgway $\mathrm{SH}$, Harrison R (eds) Handbook of marine mammals, Vol 3: The sirenians and baleen whales. Academic Press, London, p 193-240

Submitted: April 16, 2012; Accepted: July 8, 2013

Proofs received from author(s): October 11, 2013 